\title{
Group A Streptococcus pleuropneumonia associated with toxic shock syndrome in a 64-year-old woman
}

\author{
Philippe Imamdad, Patrick Miailhes, Alexie Bosch, Tristan Ferry
}

Infectious Diseases Department, Hospices Civils de Lyon, Lyon, France

Correspondence to Pr Tristan Ferry, tristan.ferry@univ-lyon1.fr

Accepted 13 April 2019

\section{DESCRIPTION}

A 64-year-old woman was admitted to hospital for fever and shortness of breath. She had a history of back pain for several years with non-steroidal anti-inflammatory drug treatment, and had had an influenza vaccination 1 month before. One week before, the patient's granddaughter was diagnosed with scarlet fever, and other cases were diagnosed in her school. Five days before, she experienced fever, chills and cough along with thorax pain. Because of the increasing level of symptoms, she came to the emergency department. On initial examination, her temperature was $39^{\circ} \mathrm{C}$, with $88 \%$ oxygen saturation and clinical signs of respiratory distress. Blood gas test with oxygen at $6 \mathrm{~L} /$ min flow rate found $\mathrm{pH}=7.41, \mathrm{PaO}_{2}=50 \mathrm{~mm} \mathrm{Hg}$ and $\mathrm{PaCO}_{2}=22 \mathrm{~mm} \mathrm{Hg}$. Creatinine concentration was $200 \mu \mathrm{mol} / \mathrm{L}$, leucocytes $40 \mathrm{G} / \mathrm{L}$ and CRP $380 \mathrm{mg} / \mathrm{L}$. Chest X-ray (figure 1A) and CT-scan (figure 1B,C) showed parenchymal condensation of the left inferior lobe with pleural effusion. She was admitted to intensive care for treatment, where she was quickly intubated due to respiratory failure. On intensive care unit admission, treatment by ceftriaxone $(2 \mathrm{~g} / 24$ hours intravenously), spiramycin (3 MUI/8 hours intravenously) and oseltamivir (150 mg twice daily orally). Chest drainage was performed, showing $800 \mathrm{cc}$ of exudative purulent liquid. The pleural liquid and the bronchoalveolar lavage revealed group A Streptococcus (GAS) in culture. Treatment was switched to amoxicillin ( $12 \mathrm{~g} / 24$ hours intravenously) and clindamycin ( $2400 \mathrm{mg} / 24$ hours intravenously). The patient underwent one dialysis session, for kidney failure, with quick improvement in renal
A

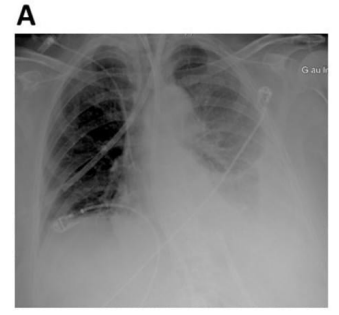

C

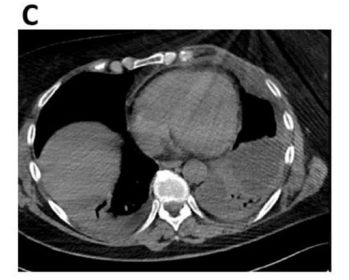

B

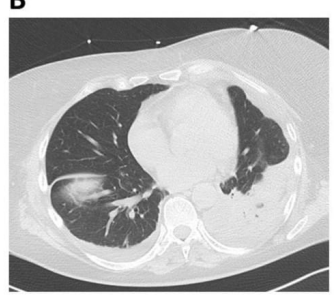

D

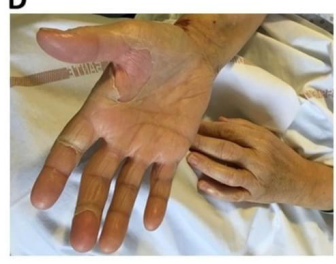

Figure 1 Chest X-ray (A), CT-scan (B and C) and photo of the hands $(D)$, showing desquamation. function. The day of admission, she started to develop a rash on the thorax that became extensive in 2-3 days, and toxic shock syndrome (TSS) was suspected. The patient improved in a few days, was quickly extubated and transferred to the infectious diseases department. Clindamycin was stopped at 7 days' treatment, and amoxicillin was continued for a total 6 weeks. The erythema disappeared, replaced by a squamous skin rash prevailing on her back and the palm of her hands (figure 1D). The GAS strain was identified as Emm3 genotype and harboured genes encoding superantigens streptococcal-pyrogenic-exotoxin A (SpeA), streptococcal-pyrogenic-exotoxin B (SpeB), streptococcal superantigen A and streptococcal mitogenic exotoxin $\mathrm{Z}$.

TSS is an acute toxin-mediated illness than can lead to multisystem organ failure. ${ }^{1}$ It can occur in GAS or Staphylococcus aureus infections and is caused by exotoxin secretion. The symptoms include fever, hypotension and diffuse macular rash that may desquamate in 1-2 weeks after onset of illness, especially on the palms and soles. Mortality in TSS is high, and remains over $50 \%$, especially in patients with streptococcal TSS, which is mainly associated with necrotising fasciitis. In the present case, the patient developed community-acquired pleuropneumonia associated with a toxinogenic agent, GAS, a rare clinical presentation of invasive GAS infection. In a French cohort of invasive GAS infections, pleuropulmonary infection represented only $9 \%$ of GAS infections, but was most frequently associated with TSS. $^{2}$ GAS and influenza B coinfection are associated with a higher mortality rate, but we exclude the diagnosis of influenza in the present case. Here, the GAS strain isolated was responsible for epidemic scarlet fever in the patient's granddaughter's school. Antibiotic therapy for patients with GAS pleuropneumonia with TSS is based on association of high-dose penicillin or amoxicillin, initially associated with clindamycin, which shows antitoxin activity in vitro. ${ }^{3}$

\section{Learning points}

Group A Streptococcus (GAS) can cause pleuropneumonia.

- GAS pleuropneumonia is frequently associated with toxic shock syndrome (TSS).

- GAS pleuropneumonia with TSS requires amoxicillin plus clindamycin as bactericidal and antitoxin antibiotherapy. 
Acknowledgements We acknowledge the National Reference Center for Streptococci (CNR-strep, Hôpital Cochin, Paris France), which performed the toxin gene profile of the strain.

Contributors PI wrote the draft of the manuscript. PM, $A B$ and TF significantly improved the manuiscript. PI, PM, AB and TF participated to the patient care.

Funding The authors have not declared a specific grant for this research from any funding agency in the public, commercial or not-for-profit sectors.

Competing interests None declared.

Patient consent for publication Obtained.
Provenance and peer review Not commissioned; externally peer reviewed.

\section{REFERENCES}

1 Lappin E, Ferguson AJ. Gram-positive toxic shock syndromes. Lancet Infect Dis 2009:9:281-90

2 Plainvert C, Doloy A, Loubinoux J, et al. Invasive group A streptococcal infections in adults, France (2006-2010). Clin Microbiol Infect 2012;18:702-10.

3 Stevens DL, Madaras-Kelly KJ, Richards DM. In vitro antimicrobial effects of various combinations of penicillin and clindamycin against four strains of Streptococcus pyogenes. Antimicrob Agents Chemother 1998;42:1266-8.

Copyright 2019 BMJ Publishing Group. All rights reserved. For permission to reuse any of this content visit

https://www.bmj.com/company/products-services/rights-and-licensing/permissions/

BMJ Case Report Fellows may re-use this article for personal use and teaching without any further permission.

Become a Fellow of BMJ Case Reports today and you can:

- Submit as many cases as you like

- Enjoy fast sympathetic peer review and rapid publication of accepted articles

- Access all the published articles

Re-use any of the published material for personal use and teaching without further permission

For information on Institutional Fellowships contact consortiasales@bmjgroup.com

Visit casereports.bmj.com for more articles like this and to become a Fellow 